\title{
Mykhailo Ryazanov
}

\section{Soviet's Legal Heritage Role in the Development of Ukrainian Law}

\section{Introduction}

The post-Soviet period, which for many years radically changed the vector of development of Ukrainian statehood, the legal system and the concept of law, has led to a different perception of the Soviet past and an ambiguous perception by various politicians and some representatives of academic groups, ranging from ruthless criticism and total rejection to the vague and even embarrassing.

For a long time, different scientific groups have been cultivating an opinion that has led to a very primitive scheme, according to which, with the fall of the UNR (Ukrainian national republic), a period of Soviet-Russian occupation of Ukraine will ensue. With this approach, we actually lose our modem history. This applies first and foremost to the fact that today's Ukraine developed in the form of the Ukrainian Soviet Socialist Republic during the Soviet era. Accordingly, it must be acknowledged that the Ukrainian SSR is not only a product of foreign aggression, but also a modern Ukrainian project. This is reflected in the fact that Ukraine is recognized by many historians during the Soviet period as a forge for the scientific elite that formed the scientific base on the territory of the entire USSR.

The Soviet period is also characterized by such important achievements for Ukraine as the Ukrainianization of cities and the formation of the Ukrainian power hierarchy. And the positions such as "we have nothing in common with the communist past, we were in the internal 
opposition, the soviet power supersedes the nature of Ukrainian citizenship - are, unfortunately, nothing else but manifestations of a deep infantilism"1.

\section{Role of Soviet revolution in Ukrainian legal development}

Ф. Tikhonovsky believes that attempts to re-consider the Soviet period in the legal development of the country are unfortunate and without consequence. What is happening today in the legal system can't be understood and analysed without taking into account the initial state of legal institutions that were formed during the Soviet era. Moreover, the current legal system is far from having completely lost its link with the soviet law: part of the soviet legislation is still in force, although it is already very small; there is continuity in some approaches and concepts ${ }^{2}$.

In A. Medushevsky's opinion "the revolutions of the twentieth century brought down weak elements of civil society. Popular "legal consciousness" triumphed over the Europeanised system of positive law which had been sacrificed to the utopian notions of the masses about the golden age. This allowed the appearance of a chimerical phenomenon of "socialist law» which, in principle, was not law, but represented its direct rejection (reflecting at the stage of its formation anarchic protest) in the shortest possible time ${ }^{3}$. In the words of the quoted author, the revolutionary project resulted in the re-transformation of traditional society in the form of retraditionalization, which was based on the primacy of ideology (revolutionary myth) over law ${ }^{4}$.

1 Rasevych V. (2017) "Sovity" i "bolshevyky" kolys i teper. Chy slid vvazhaty radianskyi period okupatsiinym? [The Soviets and Bolsheviks in the past and now. Should the Soviet period to be occupationaly considered?]. Retrieved from: https://zaxid.net/ soviti_i_bolsheviki_kolis_i_teper_n1437655. [in Ukrainian].

2 Tykhonovskyi F.Y. (2009), Ponymanye prava v sovetskoi yurydycheskoi nauke: 1917-1938 hh. [Understanding of law in the Soviet legal science: 1917-1938 years] (PhD Thesis). Moscow: Rossyiskaia akademiia hos. sluzhby pry Prezydente Rossyiskoi Federatsyy.

3 Medushevskyi A.N. (2014), Rossyiskaia pravovaia tradytsyia - opora yly prehrada?: Doklad y obsuzhdenye [Russian legal tradition - support or obstacle? Report and discussion]. Moscow: Fond "Lyberalnaia Myssyia". [in Russian].

4 Ibid. S. 2. [in Russian]. 
The legal establishment of the Soviet statehood in Ukraine took place on the $10^{\text {th }}$ of March, $1919^{5}$. Although the constitution declared Ukraine an independent state, its sovereignty existed only formally from the very beginning. As early as 1920, a workers' and farmers' union treaty was concluded between the USSR and the Ukrainian SSR, under which the two republics were part of a single military and state union.

As a result of the revolutionary changes, the process of organising a special legal system to meet the needs of the new political regime is beginning, and new legislation and law are taking shape.

\section{Methodology of soviet law}

According to V. Ukhach's opinion, the new law was characterized by following features: - The sources of law in Ukraine of that time were the soviet normative acts and the so-called revolutionary consciousness. For instance, the Statute of the People's Courts of 10 December 1918 forbade the old laws and the judges, while taking decisions, were allowed to use their own judgement and revolutionary consciousness. The characteristic feature of the Soviet laws (decrees, resolutions) was their brevity and ideological character. They did not aim to stipulate everything, but only presented the main principles. Soviet law abandoned customary law as a source of law. That period saw the emergence of so-called party law, where resolutions and resolutions of party bodies, written in declarative form, had a mandatory legal character. In the absence of legislative norms, the so-called revolutionary law and order, that is, ideological attitudes of a strictly class character, could be invoked. ${ }^{6}$ The attitude of the revolutionary right-will is marked by the fact that the specific conditions of the people's struggle for their own freedoms during the period of the civil war did not allow them to defend the soviet order in any other way?

5 Ruban A.A. (2006), Ukrayna. XX vek [Ukraine. The twentieth century] Homel: Homelskyi hosudarstvennyi unyversytet ym. F. Skoryny. [in Russian].

6 Ukhach V.Z. (2011), Persha kodyfikatsiia zakonodavstva Radianskoi Ukrainy: prychyny, etapy, osoblyvosti [The first codification of Soviet Ukraine's legislation: causes, stages, peculiarities]. Formuvannia pravovoi derzhavy v Ukraini: problemy i perspektyvy. Zbirnyk tez dopovidei. Ternopil: Vektor, pp. 96-99. [in Ukrainian].

7 Bihun V.S., Boiko I.Y., Bondaruk T.I., Vislobokov K.A., Havrylenko O.A., Zait- 
As M. Gusarova notes, during the first years of soviet power, revolutionary law and order was considered to be the basis of the principle of revolutionary legality in the soviet society and state ${ }^{8}$. And its existence was substantiated by a "normative" approach to the definition of law and the interdependence of legal consciousness and legal conduct, the recognition of the inexhaustible adherence to the rule of law as a sign of a high level of legal consciousness?

The socialist revolution of 1917 led to a fundamental socio-cultural change which involved not only a change in the whole system of values and cultural orientations of society, but also the way of social organization and the very way of life of the states which were part of the Ukrainian SSR. Therefore, this fact completely disrespects the preservation of elements of a national legal tradition after 1917 by certain states, Ukraine in particular. Therefore, according to M. Tarasov, «it is problematic to speak of the creation of any pre-revolutionary legal ideas, values, norms in the natural processes of translation and implementation in the soviet law. On the other hand, in this case not hundreds of years have passed and a sufficient number of bearers of the past legal culture remained in the professional community ${ }^{10}$. In the opinion of this author, in the drive to establish socialist law "as a new, higher type of law, different from bourgeois law not only in its content but also in its form", the soviet juridical science was first of all aware of its philosophical and

sev L.O., Ivanova A. Yu., Malyshev O.O., Muzyka I.V., Okipniuk V.T., Rominskyi Ye. V., Samoilenko O.O., Siryi M.I., Usenko I.B. (2014), Sudova vlada v Ukraini: istorychni vytoky, zakonomirnosti, osoblyvosti rozvytku [Udicial Power in Ukraine: Historical Dynamics, Regularities, Peculiarities of Development]. NAN Ukrainy. Instytut derzhavy i prava im. V.M. Koretskoho; Mizhnarodna asotsiatsiia istorykiv prava. Kyiv: Vydavnytstvo „Naukova dumka" NAN Ukrainy". [in Ukrainian].

8 Husarova M.A. (2015), Evoliutsyia kontseptsyi pravosoznanyia v sovetskoi pravovoi nauke [Evolution of concepts of legal consciousness in Soviet legal science]. Ystorycheskye, fylosofskye, polytycheskye y yurydycheskye nauky, kulturolohyia y yskusstvovedenye. Voprosy teoryy y praktyky. Tambov: Hramota, no. 11 (61), vol. II, pp. 67-71.

9 Ibid. S. 68. [in Russian].

10 Tarasov N.N. (2020), Pravovaia tradytsyia y preemstvennost v prave: metodolohycheskye osnovanyia yssledovanyia [Legal Tradition and Continuity in Law: Methodological Grounds of Research]. Rossyiskyi yurydycheskyi zhurnal. Metodolohyia prava, no. 3, pp. 5-15. 
methodological fracture not only with bourgeois, but also with all presocialist jurisprudence ${ }^{11}$. However, in continuing the discussion on this topic, the author concludes that this does not mean that soviet jurisprudence has excluded traditional, for instance, dogmatic questions of law from its attention, but it did not prevent the results of pre-revolutionary developments (although mostly in the sense of "technical jurisprudence") from being highly regarded as elements that not only could, but should be accepted and used by the soviet jurisprudence ${ }^{12}$.

As S.V. Alexeev points out, "the abolition of the old law does not mean its indifferent abolition and destruction of those general for any law figures, which were embedded in the bourgeois law. Otherwise, its study would be redundant. The new law unquestionably overrides the old, but overrides it so that the new can be created. The abolition of the old law means nothing else than the fact that the old law has lost its legal force under the new historical conditions, but remains the source of our knowledge of the old law, which we recognize for the purpose of recognizing nowadays and anticipating the future ${ }^{13}$.

\section{Legal sciences' development in Ukrainian SSR}

The Marxist-Leninist methodology was established in the legal science and the theoretical foundation was laid for the development of a fundamentally new system of legal sciences. The doctrine of law as a result of the integration of the revolutionary experience of the working class and the dictatorship of the proletariat, using the method of dialectical materialism to study legal phenomena gave rise to a new understanding of law. In the opinion of soviet legal scholars, this gave a truly scientific explanation of the processes of origin, class essence and social role of law ${ }^{15}$ and formed the type of law understanding, that led to the notion of law as a set of rules of conduct expressing the will of the ruling class, established in a legal order, as well as customs and rules of the community, that are sanctioned by the state power, the enforcement of

\footnotetext{
11 Tarasov N.N. Ibid. [in Russian].

12 Ibid. [in Russian].

13 Tykhonovskyi F.Y. Ibid. S. 8. [in Russian]
} 
which is ensured by the coercive power of the state for the purposes of protection, consolidation and development of social relations and order that are advantageous and desirable to the members of the social class ${ }^{14}$.

Thus, as Y. Shemshuchenko points out, during the Soviet period the legal science appeared to be strongly connected to the needs of the command-and-control system in terms of theoretical basis of its political decisions. However, despite the ideological pressure, this science continued to develop to a considerable extent in accordance with its own intrinsic laws during this period ${ }^{15}$.

The theoretical heritage of soviet legal scholars of the 20s and the first half of the 30s is characterized by a lively philosophical debate on the duty of law and state after the proletarian revolution. Significant number of fascinating and original conceptions of the legal understanding were proliferated that allowed a better and deeper understanding of law as a rich and self-created social phenomenon, enriched the national theory of law and state with a number of new legal catego.ries that are not comparable in Western jurisprudence and are still used in legal science today, such as legal relations, legal personality and legality ${ }^{16}$.

Scientists of Ukrainian domestic high law schools were actively involved in the expansion of the legal framework, the creation of new legal acts and in the preparation of the collection and consolidation of materials for the future extensive codification. The 1920s went down in the history of Soviet Ukrainian law as the first period of extensive codification. Over a period of a few years the codes and other systematized legislative acts were created in the main branches of Soviet law in Ukraine: The Criminal Code of the Ukrainian SSR (1922), the Code of Criminal Procedure of the Ukrainian SSR (1922), the Statute on the Courts of the Ukrainian SSR (1922), the Civil Code of the Ukrainian SSR (1922), the Land Code of the Ukrainian SSR (1922), Labour Code of the Ukrainian SSR (1922), Education Code of the Ukrainian SSR (1922), Law on Forests of the Ukrainian SSR (1923), Civil Procedure Code of the

14 Tykhonovskyi F.Y. Ibid. S.11. [in Russian].

15 Shemshuchenko Yu.S. (2019), Instytutsiini aspekty orhanizatsii pravoznavchykh naukovykh doslidzhen $v$ Ukraini [Institutional aspects of organization of legal science research in Ukraine]. Pravova derzhava, no. 30, pp. 3-23.

16 Tykhonovskyi F.Y. Ibid. S. 3-4; 8; 11. [in Russian]. 
Ukrainian SSR (1924), Provisional Building Regulations of the Ukrainian SSR (1924), Veterinary Code of the Ukrainian SSR (1925), Corrective Labour Code of the Ukrainian SSR (1925) ${ }^{17}$.

Despite its external similarity to bourgeois codes, the Ukrainian legislation of the early period was in favour of the "interests of the dictatorship of the proletariat". The same articles of the Soviet and Western European codes were used textually for different purposes, in diametrically opposed social conditions and were applied by courts which took fundamentally different positions. At the same time, this process was fully in line with the historical social and economic conditions that prevailed ${ }^{18}$.

The relevance of conducting such work was caused by the need to formalise the legal forms of new social relations and the need to systematise the domestic legislation, to eliminate the existing inequalities and gaps in $\mathrm{it}^{19}$.

I. Usenko, investigating the codification works in the Ukrainian SSR, noted that although the first codification of the Ukrainian SSR legislation was based on the principle of uniformity of the Soviet legislation and was exemplified by the legislative acts of the USSR, nevertheless, it also took into account some specific Ukrainian national conditions. For example, the Criminal Code of the Ukrainian SSR had 11 new articles as compared to the Soviet one; a number of differences related to the existence of committees of independent villagers in the Ukrainian SSR, local specific land proceedings, specific conditions of the class struggle in the villages, etc., were enacted in The Land Code $^{20}$. Referring to the analysis of the Soviet legislation of that time, Usenko noted that «Ukrainian lawyers were sometimes ahead of their Russian colleagues. For example, the draft Civil Procedure Code published in Ukraine in 1922 was used

17 Kyvalov S.V. (ed.) (2016), Vvedenye v Ukraynskoe pravo [Introduction to Ukrainian Law]. Odesa: Natsyonalnyi unyversytet "Odesskaia yurydycheskaia akademyia".

18 Vvedenye v Ukraynskoe pravo [Introduction to Ukrainian Law]. Ibid. S. 73.

19 Usenko I.B. (2007),, Kodyfikatsiini roboty v URSR. Persha kodyfikatsiia Ukrainskoho-radianskoho zakonodavstva [Codification works in the Ukrainian SSR. The First Codification of the Ukrainian-Russian Legislation]. NAN Ukrainy. Instytut istorii Ukrainy. Kyiv: V-vo "Naukova dumka". Retrieved from: http://www.history.org.ua/?termin=Kodyfikaciyni_roboty_V_USRR [in Ukrainian].

20 Ibid. Retrieved from: http://www.history.org.ua/?termin=Kodyfikaciyni_roboty_V_USRR [in Ukrainian]. 
to prepare a similar Russian code. It is the Ukrainian SSR where the first Administrative Code and the Code of Laws on Public Education were adopted. The Ukrainian SSR was significantly more successful than the USSR in its efforts to prepare a substantive codification, which resulted in the publication of the Systematic Collection of Current Laws of the Ukrainian SSR ${ }^{21}$.

It should be noted that the Administrative Code of the Ukrainian SSR 1927 had no counterparts in other republics of the Soviet Union and at that time was among the first of its kind in Europe. The high substantive and technical-legal level of the Administrative Code is evidenced by the fact that it has been in force for a long period, having received a new edition in $1956^{22}$.

In 1940-1950 on the territory of Ukraine the previously adopted republican codes and laws with archaic norms that did not correspond to the political and socioeconomic conditions were still in force. This called for a streamlining of legislation and removal of outdated norms from the codes. Moreover, the new political leadership of the Soviet Union in the practice of state building declared the replacement of the long-standing Soviet doctrine of the dictatorship of the proletariat to the model of the "nationwide state". This entailed a real transformation of the social basis of the soviet society, bringing it closer to communist self-government and, accordingly, making it necessary to bring the legal system up to the society's level of the development ${ }^{23}$.

In the codification process in the Ukrainian SSR, the attention of scientists was focused on the study of the constitutional development of the Ukrainian SSR, the legal nature and basic principles of the Constitu-

21 Ibid. Retrieved from: http://www.history.org.ua/?termin=Kodyfikaciyni_roboty_V_USRR [in Ukrainian].

22 Ivanov V.M. Persha kodyfikatsiia radianskoho prava v Ukraini [The first codification of soviet law in Ukraine]. Istoriia derzhavy i prava Ukrainy: pidruchnyk [History of power and law of Ukraine: a handbook]. Retrieved from: https://law.wikireading. ru/41074 [in Ukrainian].

23 Terliuk I.la. Istoriia derzhavy i prava Ukrainy. Osoblyvosti provedennia Druhoi kompleksnoi kodyfikatsii zakonodavstva URSR [History of Power and Law of Ukraine. Peculiarities of the Second Complex Codification of the Law of the Ukrainian SSR]. Retrieved from: https://westudents.com.ua/glavy/61387-osoblivost-provedennya-drugo-kompleksno-kodifkats-zakonodavstva-ursr.html [in Ukrainian]. 
tion. Important issues of state-political governance and State-building haven't been neglected ${ }^{24}$. But it must be acknowledged that Soviet constitutional law, like other branches of law, was based on Marxist-Leninist doctrines and the political-legal theories developed on their basis. According to it the main objective of the constitutional order is to protect the socialist state, but not the rights of workers. Notwithstanding this, constitutional scholars have developed theoretical knowledge of constitutional phenomena and processes and trained national scientific personnel in the field of constitutional law, which became the basis for the formation of constitutional institutions in an independent Ukraine ${ }^{25}$.

According to A.R. Krusyan, the paradigm of constitutionalism in the Ukrainian SSR was shaped by the performance of the Soviet constitutions (1919, 1929 and 1937). These laws provided the necessary constitutional and legal basis for the changes that took place in the state and society after the revolution in Russia, and now the Fundamental Laws have made a certain contribution to the formation of the scientific and practical paradigm of constitutionalism. In particular, the democratic principles, methods and techniques of governing were enshrined in the constitution and the political, social, economic and cultural rights of citizens were consolidated ${ }^{26}$.

The legal heritage in the sphere of administrative law and state building should be mentioned that already in the 60-70s in Ukraine there is an active research in the areas that have covered, in particular, the problematics of: - Theory and practice of state management improvement; - legal regulation of state management in the sphere of state administration; - organization and legal support of scientific and technological development of the country. Formed in the framework of Ukrainian school fundamentals of Ukrainian administrative law science and a set of fundamental and applied knowledge is recognized as the basic

24 Shemshuchenko Yu.S. Ibid. S. 4. [in Ukrainian].

25 Kozachenko A.I. (2020), Istoriia rozvytku konstytutsionalizmu v Ukraini: Navch. Posibnyk [History of the development of constitutionalism in Ukraine: Textbook]. Poltava: "Astraia". [in Ukrainian].

26 Krusian A.R. (2010), Suchasnyi ukrainskyi konstytutsionalizm: teoriia i praktyka [Modern Ukrainian constitutionalism: theory and practice] (PhD Thesis). Odesa: Odeska yurydychna akademiia. 
component of the theoretical and methodological training of the current generation of scholars of public administration and administrative law ${ }^{27}$.

It should be noted that during the Soviet period the Ukrainian school of administrative law was one of the most influential not only in the Ukrainian SSR, but also beyond its borders. Thus, L. Mihnevich noted, that already during early Soviet period domestic scholars were actively researching the legal nature of administrative law as a public sphere, forms of administrative activity, types of administrative acts, interrelations of implementation of public rights of citizens and powers of governing bodies. The focus of their interests was forwarded to analysing the principles of legality in the sphere of governance, administrative measures, specific features of implementation of the offical's liability, etc. ... as a special part of administrative law in the 1920s. The problems of housing, land, cooperative and food law ${ }^{28}$ were also investigated. The Ukrainian SSR law schools, united by the solidarity of scientific thought and joint scientific ideology influenced the formation other fundamental branches of law, contributed to enhancing the scientific potential of the country, and ensured the advancement of scientific knowledge.. In preserving this progression, a significant role is played by studying the heritage of their predecessors, and getting acquainted with their methods of work. The previous achievements are the starting point for the further development of learning tools and methods, systems of knowledge, ideas, directions, searches, because the occurrence is the organic integration of the two moments: inheritance and critical transformation ${ }^{29}$. In the opinion of the quoted author, the process of progress in science, as well as in society as a whole, is expressed in the terms "tradition" and "innovation" as two opposing, dialectically related sides of the unified process of science development: innovation grows out of tradition ${ }^{30}$.

27 Shemshuchenko Yu.S. Ibid. S. 4-5. [in Ukrainian].

28 Mikhnevych L.V. (2019), Administratyvne pravo rannoho radianskoho periodu [Administrative law of the early soviet period]. Pravove rehuliuvannia ekonomiky, no. 18, pp. 7-18.

29 Vyshnovetska S.V. (2014) Naukova shkola yak forma rozvytku nauky trudovoho prava [Scientific school as a form of development of labor law science]. Mizhdystsyplinarni humanitarni studii. Seriia: Pravnychi nauky, vol. 1, pp. 15-21.

30 Vyshnovetska S.V. Ibid. [in Ukrainian]. 
In the process of the evolution of the soviet legal system, gradually are stated the people's, democratic legal values, the beginnings of legality, which oppose the ruling party's overpowering rule. The transition from a totalitarian system of government to a political and legal regime of an authoritarian nature is underway. This engender the evolving further democratic principles ${ }^{31}$.

The tendencies in the development of the system of civil law were caused by the complication of public life and the development of social relations. The trends in the development of the system of civil law had a significant impact on the formation of the Ukrainian legal system and were associated with the expansion of the old and the emergence of new branches, sub-branches and institutions of the law, the withdrawal of outdated, such as, The legal institutions and regulations, remnants of a totalitarian social and political state ideology and the development of new sets of legal norms, Standardisation, integration and unification of the legal regulation of social relations, i.e. bringing the current laws to a single system and eliminating discrepancies in the legal regulation.

\section{Conclusion}

The deepening of the process of differentiation of the legal regulation of social relations has also become one of the possible ways of improving the system of Ukrainian legislation, which has contributed to increasing the effectiveness of the impact of this system on the political, social and economic life of the country.

It is obvious that most of the legal categories and legal constructs used in the modern domestic legal science such as: concepts of law, the notion of law, its system, nature of legal norms, law-making, interpretation and application of law were developed by early law scholars. In this way, it is possible to see the unappreciated contribution to the development of national legal thinking by the early law experts and, in general, the role of the continuity in the evolution of the national legal system.

31 Nadezhyn V.Y. (2005), Osobennosty sovetskoi pravovoi systemy [Peculiarities of the Soviet legal system]. Sovremennye problemy hosudarstva y prava: Sbornyk nauchnykh trudov. Novgorod, vol. 8, pp. 89-101. 


\section{References}

Bihun V.S., Boiko I.Y., Bondaruk T.I., Vislobokov K.A., Havrylenko O.A., Zaitsev L.O., Ivanova A.Yu., Malyshev O.O., Muzyka I.V., Okipniuk V.T., Rominskyi Ye.V., Samoilenko O.O., Siryi M.I., Usenko I.B. (2014), Sudova vlada v Ukraini: istorychni vytoky, zakonomirnosti, osoblyvosti rozvytku [Udicial Power in Ukraine: Historical Dynamics, Regularities, Peculiarities of Development]. NAN Ukrainy. Instytut derzhavy i prava im. V.M. Koretskoho; Mizhnarodna asotsiatsiia istorykiv prava. Kyiv: Vydavnytstvo "Naukova dumka" NAN Ukrainy". [in Ukrainian].

Husarova M.A. (2015), Evoliutsyia kontseptsyi pravosoznanyia v sovetskoi pravovoi nauke [Evolution of concepts of legal consciousness in Soviet legal science]. Ystorycheskye, fylosofskye, polytycheskye y yurydycheskye nauky, kulturolohyia y yskusstvovedenye. Voprosy teoryy y praktyky. Tambov: Hramota, no. 11 (61), vol. II, pp. 67-71.

Ivanov V.M. Persha kodyfikatsiia radianskoho prava $v$ Ukraini [The first codification of soviet law in Ukraine]. Istoriia derzhavy i prava Ukrainy: pidruchnyk [History of power and law of Ukraine: a handbook]. Retrieved from: https://law.wikireading.ru/41074 [in Ukrainian].

Kozachenko A.I. (2020) Istoriia rozvytku konstytutsionalizmu v Ukraini: Navch. Posibnyk [History of the development of constitutionalism in Ukraine: Textbook]. Poltava: "Astraia". [in Ukrainian].

Krusian A.R. (2010) Suchasnyi ukrainskyi konstytutsionalizm: teoriia i praktyka [Modern Ukrainian constitutionalism: theory and practice] (PhD Thesis). Odesa: Odeska yurydychna akademiia.

Kyvalov S. V. (ed.) (2016) Vvedenye v Ukraynskoe pravo [Introduction to Ukrainian Law]. Odesa: Natsyonalnyi unyversytet „Odesskaia yurydycheskaia akademyia".

Medushevskyi A.N. (2014), Rossyiskaia pravovaia tradytsyia - opora yly prehrada? : Doklad y obsuzhdenye [Russian legal tradition - support or obstacle? Report and discussion]. Moscow: Fond „Lyberalnaia Myssyia". [in Russian].

Medushevskyi A.N. (2017), Russkaia revoliutsyia y problemy rossyiskoi pravovoi tradytsyy [The Russian Revolution and the Problems of the Russian Legal Tradition]. Polytycheskaia ystoryia russkoi revoliutsyy: normy, ynstytuty, formy sotsyalnoi mobylyzatsyy $v$ XX veke. MoscowSaint-Petersburg: Tsentr humanytarnykh initsyativ. [in Russian]. 
Mikhnevych L.V. (2019), Administratyvne pravo rannoho radianskoho periodu [Administrative law of the early soviet period]. Pravove rehuliuvannia ekonomiky, no. 18, pp. 7-18.

Nadezhyn V.Y. (2005), Osobennosty sovetskoi pravovoi systemy [Peculiarities of the Soviet legal system]. Sovremennye problemy hosudarstva y prava: Sbornyk nauchnykh trudov. Novgorod, vol. 8, pp. 89-101.

Rasevych V. (2017), „Sovity” i „bolshevyky” kolys i teper. Chy slid vvazhaty radianskyi period okupatsiinym? [The Soviets and Bolsheviks in the past and now. Should the Soviet period to be occupationaly considered?]. Retrieved from: https://zaxid.net/soviti_i_bolsheviki_kolis_i_teper_n1437655 [in Ukrainian].

Ruban A.A. (2006), Ukrayna. XX vek [Ukraine. The twentieth century] Homel: Homelskyi hosudarstvennyi unyversytet ym. F. Skoryny. [in Russian].

Shemshuchenko Yu.S. (2019), Instytutsiini aspekty orhanizatsii pravoznavchykh naukovykh doslidzhen v Ukraini [Institutional aspects of organization of legal science research in Ukraine]. Pravova derzhava, no. 30, pp. 3-23.

Tarasov N.N. (2020), Pravovaia tradytsyia y preemstvennost v prave: metodolohycheskye osnovanyia yssledovanyia [Legal Tradition and Continuity in Law: Methodological Grounds of Research]. Rossyiskyi yurydycheskyi zhurnal. Metodolohyia prava, no. 3, pp. 5-15.

Terliuk I.Ia., Istoriia derzhavy i prava Ukrainy. Osoblyvosti provedennia Druhoi kompleksnoi kodyfikatsii zakonodavstva URSR [History of Power and Law of Ukraine. Peculiarities of the Second Complex Codification of the Law of the Ukrainian SSR]. Retrieved from: https:// westudents.com.ua/glavy/61387-osoblivost-provedennya-drugokompleksno-kodifkats-zakonodavstva-ursr.html [in Ukrainian].

Tykhonovskyi F.Y. (2009), Ponymanye prava v sovetskoi yurydycheskoi nauke: 1917-1938 hh. [Understanding of law in the Soviet legal science: 1917 - 1938 years] (PhD Thesis). Moscow: Rossyiskaia akademiia hos. sluzhby pry Prezydente Rossyiskoi Federatsyy.

Ukhach V.Z. (2011), Persha kodyfikatsiia zakonodavstva Radianskoi Ukrainy: prychyny, etapy, osoblyvosti [The first codification of Soviet Ukraine's legislation: causes, stages, peculiarities]. Formuvannia 
pravovoi derzhavy v Ukraini: problemy i perspektyvy. Zbirnyk tez dopovidei. Ternopil: Vektor, pp. 96-99. [in Ukrainian].

Usenko I.B. (2007), Kodyfikatsiini roboty v URSR. Persha kodyfikatsiia Ukrainskoho-radianskoho zakonodavstva [Codification works in the Ukrainian SSR. The First Codification of the UkrainianRussian Legislation]. NAN Ukrainy. Instytut istorii Ukrainy. Kyiv: V-vo "Naukova dumka". Retrieved from: http://www.history.org. ua/?termin=Kodyfikaciyni_roboty_V_USRR [in Ukrainian].

Vyshnovetska S.V. (2014), Naukova shkola yak forma rozvytku nauky trudovoho prava [Scientific school as a form of development of labor law science]. Mizhdystsyplinarni humanitarni studii. Seriia: Pravnychi nauky, vol. 1, pp. 15-21.

\section{Summary}

The formation of soviet law in Ukraine was inevitably connected with the spread of soviet power. Along with the soviet institutions, legislative acts of Soviet Union were spread on the territory of Ukraine and replaced the earlier normative acts. The legal system in Ukraine was in fact formed on the basis of the ideological foundations created by the Soviet Union.

However, it is a fact that the system of law in Russia after the October Revolution of 1917 did not emerge from scratch, but was built on already existing legal traditions. They are based on three basic sources: German legal tradition, which influenced pre-revolutionary Russian legal culture, Russia's own legal culture and, of course, official socialist ideology, as well, which provided the legal system with a link to the legal past, which in turn ensured the advancement of the legal system.

The legal development of Ukraine during the soviet period was based on the adapting of Ukrainian legal past to the needs of the soviet period. Accordingly, this approach confirms the preservation of the link between the Ukrainian legal past and the present. That means, that the processes that are happening nowadays in the legal system of the modern Ukraine cannot be analyzed without taking into account the initial state of legal institutions that were formed Before and After the soviet period.

Therefore, the preservation and analysis of the Ukrainian SSR's law as a legal heritage of Ukraine will make it possible to ensure progress in the evolution of the modern Ukrainian legal system.

Keywords: legal heritage, soviet legal heritage, Ukrainian legal system, legal advancement, soviet legal traditions 